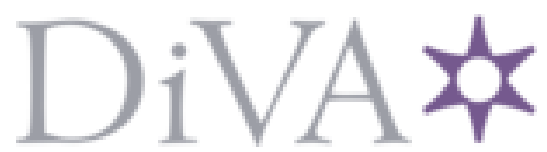

http://www.diva-portal.org

\title{
Postprint
}

This is the accepted version of a paper published in International Studies Quarterly. This paper has been peer-reviewed but does not include the final publisher proof-corrections or journal pagination.

Citation for the original published paper (version of record):

Melander, E. (2005)

Gender Eqaulity and Intrastate Armed Conflict

International Studies Quarterly, 49(4): 695-714

https://doi.org/10.1111/j.1468-2478.2005.00384.x

Access to the published version may require subscription.

N.B. When citing this work, cite the original published paper.

Permanent link to this version:

http://urn.kb.se/resolve?urn=urn:nbn:se:uu:diva-68862 
This is the peer reviewed version of the following article:

Melander, Erik, 2005. Gender Equality and Intrastate Armed

Conflict. International Studies Quarterly 49 (4), 695-714,

which has been published in final form at

https://doi.org/10.1111/j.1468-2478.2005.00384.x.

This article may be used for non-commercial purposes in accordance with Wiley Terms and Conditions for Use of Self-Archived Versions.

To cite, please use the following information: Melander, Erik, 2005. Gender Equality and Intrastate Armed Conflict. International Studies Quarterly 49 (4), 695-714.

\section{Gender Equality and Intrastate Armed Conflict}




\begin{abstract}
In this article I examine to what extent gender equality is associated with lower levels of intrastate armed conflict. I use three measures of gender equality: [1] a dichotomous indicator of whether the highest leader of a state is a woman; [2] the percentage of women in parliament; and [3] the female-to-male higher education attainment ratio. I argue that the first two measures in particular capture the extent to which women hold positions that allow them to influence matters of war and peace within a state. I further argue that all three measures, but especially the last two, capture how women are valued relative to men in a society, i.e., the relative degree of subordination of women. Whereas female state leadership has no statistically significant effect, more equal societies, measured either in terms of female representation in parliament or the ratio of female-to-male higher education attainment, are associated with lower levels of intrastate armed conflict. The pacifying impact of gender equality is not only statistically significant in the presence of a comprehensive set of controls but also strong in substantive terms.
\end{abstract}




\section{GENDER EQUALITY AND INTRASTATE ARMED CONFLICT}

The claim developed in feminist theory that societies based to a lesser extent on gender hierarchies are less beset by collective violence bears directly on some of the most central questions in the study of International Relations. Following a debate about the relationship between this field of research and feminist scholarship (Tickner, 1997; Hermann, 1998; Keohane, 1998; Marchand, 1998; Tickner, 1998), numerous studies have been published in the field of International Relations that test the implications of feminist theories using systematically gathered evidence and transparent and replicable methods. ${ }^{1}$ Several studies have found a positive relationship between gender equality in a state and peaceful relations to other states (Caprioli, 2000; Caprioli and Boyer, 2001; Caprioli, 2003; Regan and Paskeviciute, 2003). One study finds that gender equality is associated with less state-sponsored personal integrity rights abuse (i.e., political imprisonments, torture, killings, and disappearances) domestically (Melander, 2005). In the first quantitative study on the relationship between gender equality and intrastate armed conflict, Mary Caprioli finds that gender equality contributes to peace also within states (Forthcoming). In this article I present a study that examines gender equality and intrastate armed conflict from a different angle. While my results are in line with the gist of Caprioli's findings, I also shed light on novel aspects of the relationship between gender equality and intrastate peace.

I use three measures of gender equality: [1] a dichotomous indicator of whether the highest leader of a state is a woman; [2] the percentage of women in parliament; and [3] the female to male higher education attainment ratio. I argue that the first two measures in particular capture the extent to which women hold positions that allow them to influence matters of war 
and peace within a state. I further argue that all three measures, but especially the last two, capture how women are valued relative to men in a society, i.e., the relative degree of subordination of women. In her study, Caprioli used fertility rate and percent women in the labor force as measures of gender equality.

Like Caprioli, I use data on state involvement in conflict collected by the Uppsala Conflict Data Project (Gleditsch, Wallensteen, Eriksson, Sollenberg, and Strand, 2002). Intrastate armed conflict is in line with the Uppsala definition conceived of as a contested incompatibility that concerns government and/or territory where the use of armed force between two parties, one of which is the government of a state and the other one or more opposition groups, results in at least 25 battle-related deaths in a year. Whereas Caprioli examines the impact of gender equality on the risk of intrastate conflict onset, I study changes in the level of intrastate conflict, ranging from peace over minor armed conflict to full-scale civil war. The difference between a minor armed conflict and a war as defined by the Uppsala project is that conflicts resulting in at least 25 but no more than 999 battle-related deaths in one year are coded as minor conflicts whereas those conflicts causing at least 1000 battle-related deaths in one year are considered to be wars.

Whereas female state leadership has no statistically significant effect, more equal societies, measured either in terms of female representation in parliament or the ratio of female to male higher education attainment, are indeed associated with lower levels of intrastate armed conflict. These effects of gender equality hold in the presence of a comprehensive set of control variables.

In the rest of this article, I proceed as follows. I start off the theoretical section by summarizing the feminist arguments that hold that gender equality ought to be associated with 
less collective violence. I then introduce the hypotheses. Next, I review previous empirical findings on the determinants of state involvement in armed conflict, and present and motivate my control variables. The subsequent section deals with research design issues. Finally, I present the results and round off the article with a summary and conclusions.

\section{LINKING GENDER EQUALITY AND INTRASTATE ARMED CONFLICT}

Why would gender equality be associated with peace? The theoretical answers to this question have been developed in some detail by others (see, e.g., Tickner, 1992; Caprioli, 2000; Goldstein, 2001; Tickner, 2001), and I will build on these previous arguments. Basically, more equitable societies may be more peaceful because women have a say over matters of war and peace in such societies, and women are generally more averse to war then men. Alternatively, more equitable societies may be more peaceful because the norms of inviolability and respect that define equal relations between women and men are carried over also to wider relations in society, e.g., vis-à-vis ethnic minorities or political opponents. The first explanation is based on the assumption that female aversion to violence is inherent in the essential nature of women, and is therefore referred to as the essentialist argument. The second argument emphasizes that gender roles and their accompanying attitudes are socially constructed; hence, it is referred to as the constructivist argument. These two explanations are not mutually contradicting on logical grounds, and each may thus account for some part of any relationship between gender equality and peace that is observed. Next, I will briefly present first the essentialist argument and then the constructivist argument. 
The Essentialist Argument

Underlying this argument is a belief that there are certain qualities that women have because of their reproductive role. It is believed that aversion to violence and preference for peaceful methods of dealing with conflicts come together with the unique female ability to give birth and the skills of mothering transmitted from experienced mothers to girls and young women. In line with this reasoning, numerous studies show that women tend to express attitudes that are more negative to the use of force in various contexts (Frankovic, 1982; Smith, 1984; de Boer, 1985; Shapiro and Mahajan, 1986; Fite, Genest, and Wilcox, 1990; McGlen and Sarkees, 1993; Togeby, 1994; Tessler and Warriner, 1997).

Given this view of the essential nature of women, it is to be expected that women state leaders and other women in influential positions, e.g., parliamentarians, would on the average do more to try to prevent societal problems from growing into armed conflicts and to deescalate armed conflicts when they occur, than men in similar positions. For example, they might advocate that resources that are intended for military responses to internal conflicts might be redirected toward rectifying societal ills and injustices that are perceived to be underlying causes of the conflict. Since they view war as more costly and repugnant, they would perhaps also be willing to make more concessions on behalf of the state in order to placate separatists and the like. For them, factors such as the prestige, or even the territorial integrity, of the state may weigh less relative to the costs of war. Granted, people who are generally more averse to 
violence may nevertheless be among those most supportive of the use of force if the purpose clearly is to reduce the overall level of violence as, e.g., when some humanitarian interventions are at issue. But as a general proposition, it seems reasonable to expect that the empowerment of people who are more averse to violence would translate into less internal armed conflict within a society.

There are, however, important feminist arguments that qualify the general essentialist argument outlined above. One argument maintains that female leaders can only be expected to make a distinct feminine imprint on policy to the extent that they are supported from below by a critical mass of other influential women: "It is widely believed that a supportive level of critical mass is obtained when at least one third of parliamentary, ministerial or other executive positions are occupied by women" (Fleschenberg, 2003:10). This points to the need to test whether there is an association between female state leaders and intrastate peace that only emerges as female representation in parliament increases. Such a test would thus examine the combined impact of the two measures of political gender equality.

When we consider the potential peaceful influence of female representation in parliament, it becomes necessary to take into account that many parliaments operate within very undemocratic contexts, e.g., the parliament in Iraq under Saddam Hussein. Whereas the highest leader of a state per definition wields influence, parliamentarians in such rubber-stamp legislatures cannot be expected to impinge much on questions of war and peace. If we, in line with the essentialist argument, expect to find a relationship between gender equality and intrastate peace because we count on women in parliament to exert a peaceful influence then, I submit, we must also expect this influence to be conditioned by the level of institutional democracy. Thus, in my interpretation the essentialist argument would lead us to expect the 
pacifying influence of female parliamentarian representation to be stronger in more democratic states. This line of reasoning suggests that in addition to testing for the direct effect of female representation in parliament, it is also necessary to test for the combined impact of female representation in parliament and the level of institutional democracy.

Again, where the impact of female representation in parliament is concerned, it is pertinent to take into account the qualifying argument that a minimum critical mass may be required before female parliamentarians can exert any distinct feminine influence. This possibility can be tested by examining whether the degree of female parliamentary representation above one-third of the seats has a stronger impact than female parliamentary representation in general.

\section{The Constructivist Argument}

Whereas the essentialist argument is based on attitudinal differences that supposedly are inherent in the biological sexes, the constructivist argument focuses on how attitudes to violence and the use of force may be influenced by socially constructed gender roles. In this perspective, female aversion and male predisposition to violence have less to do with the biological sexes and more to do with certain definitions of femininity and masculinity with which people identify. Since gender roles are believed to be socially constructed and to evolve in response to other developments in society, they are also seen as changeable. Nevertheless, there are two central themes in the construction of gender roles that reoccur throughout more or less all known 
cultures. First, boys and men are prepared for the potential function as warriors, whereas women are assigned the role of caring and nursing. Second, gender roles legitimize the subordination of women (Tickner, 1992; Goldstein, 2001; Tickner, 2001).

The dominant warlike role of men and the subordinated nursing role of women are interdependent in that boys and men are made aware that acting tough and warlike is considered the ultimate test of manhood, and those who fail to measure up will be shamed by both sexes in terms that imply that they are now demoted to the lowly status of girls and women (e.g., in the English language "sissy", derived from sister, or "pussy"). As a consequence, many men tend to identify with and act out a definition of masculinity that stresses the necessity and honor of violently defending one's name and the interests of the group. Most men are also trained from boyhood to suppress emotions and withstand pain. Femininity is the subordinated contrast category and defined more in terms of submission and empathy. Many girls and women assume the role of the audience in front of whom the men must prove themselves. They provide material and emotional support for warlike men and shame and ridicule those deemed unmanly (Tickner, 1992; Goldstein, 2001; Tickner, 2001).

These traditional gender roles not only prescribe male violence as means of establishing domination and protecting honor, but also legitimate the subordination of women. What is more, these roles are also highly consistent with chauvinism and imposing behavior toward other groups besides women that are similarly defined as inferior, e.g., sexual and ethnic minorities, and political opponents. Fish states the following when summarizing some of this literature: "Differentials between male and female literacy rates ... reflect social relations in the family and in the immediate community, and the character of these relations may reproduce themselves at higher levels. Several leading authors have argued that the repressiveness and 
unquestioned dominance of the father in the family and the male in relations between men and women replicate themselves in broader society, creating a culture of domination, intolerance, and dependency in social and political life" (Fish, 2002:30). Conversely, in societies characterized by more equal gender roles, the norms of respect and inviolability that characterize an individual's closest relations are also expected to carry over to more distant relations, thereby strengthening societal norms that reject abuse and violence. This is why, according to the constructivist argument, gender equality can be expected to be associated with less collective violence, including fewer, less intensive, and shorter internal armed conflicts (Tickner, 1992; Goldstein, 2001; Tickner, 2001).

The constructivist argument linking gender equality and peace thus turns on the normative aversion to violence that is believed to pervade societies in which people tend to identify with more equal gender roles. Once men begin to identify with a form of masculinity that discards warlike behavior as the test of manhood, and rejects the subordination of women, they are expected to be no less averse to violence than women that similarly deny the legitimacy of their subordination and of violence as a means of imposing domination. An attitudinal study from four countries in the Middle East confirms this: women generally tend to be more averse than men to force as an instrument of dealing with conflicts, but this gender gap disappears when attitudes to equality between women and men are taken into account; then, the men and women that are in favor of equality between women and men also tend to be the most averse to force as a policy instrument (Tessler et al., 1997).

In this line of reasoning, no particular explanatory importance is thus attributed to the decision-making impact of women in influential positions. Seen in light of the essentialist argument, the female leadership indicator and the percentage women in parliament function as 
measures of the decision-making impact of women, but where the constructivist argument is concerned, what we need to measure is instead the importance of gender norms that reject the subordination of women. I assume that it is more likely a woman may become the highest leader of the state, or a parliamentarian, when the norms of equality between women and men are more widespread. This means that the female leadership indicator and the percentage women in parliament can be used as proxies for how widespread these norms are in a society. The female leadership indicator is perhaps the least reliable proxy in the context of the constructivist argument since quite a few women leaders may have come to power in very unequal states despite their gender because of the "role given to kinship in case of succession problems in developing countries", or other dynastic reasons (Fleschenberg, 2003:22). To the extent that these women are promoted for dynastic reasons sooner than in recognition of their own merits, their promotion can hardly be seen as indicative of norms of equality between women and men. As a robustness check, I will test what happens if the female leadership indicator is divided into two separate dummies, one for dynastic women leaders and one for non-dynastic women leaders. In parallel to the essentialist argument, the constructivist argument also implies that the benign impact of female parliamentary representation may be stronger the higher the level of institutional democracy within which the parliament functions. In the context of the constructivist argument, female representation in parliament is more likely to genuinely reflect norms of gender equality if the parliament is powerful. In less democratic states, it may be suspected that ruling elites dominated by men may encourage female parliamentary representation as a relatively convenient and inconsequential way of creating a progressive facade while women nevertheless remain subordinated and excluded from the real power. 
The third measure of gender equality used in this study, the ratio of female-tomale higher education attainment, is chosen so as to capture the logic of the constructivist argument in the first hand. It is defined as the percentage of the female population age 25 and over that has attained higher schooling divided by the percentage of the male population age 25

and over that has attained this level of schooling. ${ }^{2}$ This ratio, I submit, ought to reflect roughly to what extent traditional gender roles that prescribe the subordination of women have been replaced by more equal gender roles throughout a society. This is thus a mass level socioeconomic indicator in contradistinction to the two previously introduced elite-level measures of political gender equality. In order to isolate the impact of this ratio, I will also include a measure of the total (female and male) education level as a control.

\section{HYPOTHESES}

Most research on the causes of internal armed conflict and civil war has focused on the onset of conflict. However, the arguments in the preceding sections do not imply that the effect of gender equality must be limited to possibly reducing the risk of conflict onset; also affected could be the risk that an armed conflict escalates and the chance that an ongoing armed conflict can be deescalated. I will test for the effects of gender equality on changes in the level of internal armed conflict, ranging from peace over minor armed conflict to full-scale civil war. ${ }^{3}$

The main objective of this study is to test whether gender equality is associated with lower levels of intrastate armed conflict. The quantitative study of feminist theories of 
collective violence is at an early stage, and critical tests that could decisively ascertain to what extent the essentialist argument or the constructivist argument agree with the empirical record have not been developed yet. The two arguments have similar empirical implications for the relationship between various quantitative indicators of gender equality, on the one hand, and collective violence on the other hand.

My first hypothesis on the relationship between gender equality and internal armed conflict focuses on the potential role of women state leaders. ${ }^{4}$ Both the essentialist and the constructivist arguments imply that the tenure of women leaders is associated with lower levels of internal armed conflict, although this measure of gender equality may be a less valid measure of the norms of equality that are invoked in the constructivist argument:

H1: States with a woman leader have lower levels of internal armed conflict than states with a man as its highest leader.

A variant of the essentialist argument claims that women leaders require the support of a critical mass of other women in high positions in order to make a distinctively feminine impact on policy outcomes. This auxiliary essentialist argument about the importance of a critical mass is reflected in the second hypothesis, which posits that female state leadership in interaction with female representation in parliament has a benign effect on the level of intrastate armed conflict: ${ }^{5}$

$\mathrm{H} 2$ : The higher the rate of female representation in parliament, the stronger the pacifying effect of female state leadership will be. 
Both the essentialist and the constructivist arguments imply that the percentage of women in parliament is associated with lower levels of intrastate armed conflict. ${ }^{6}$ This is the theme of the third hypothesis:

H3: The higher the rate of female representation in parliament, the lower a state's level of intrastate armed conflict will be.

The critical mass argument motivating $\mathrm{H} 2$ is applicable also to the possible effect of the rate of female parliamentary representation. This auxiliary essentialist argument is taken into account in the fourth hypothesis:

H4: Female representation in parliament does not affect the level of intrastate armed conflict until representation exceeds one-third.

Both the essentialist and constructivist arguments suggest that the effect of female parliamentary representation is conditioned by the level of institutional democracy within which a parliament functions. The fifth hypothesis captures this interaction effect:

H5: The more democratic the state, the stronger the pacifying effect of female representation in parliament will be.

In line with the constructivist argument, the sixth and last hypothesis reflects the possible role of the ratio of female-to-male higher education attainment: 
H6: The higher the female-to-male higher education attainment ratio, the lower a state's level of intrastate armed conflict will be.

The constructivist argument implies that H6 ought to be confirmed. Although the essentialist argument does not forbid that there may be such an association between the female-to-male education ratio and peace, the existence of such a relationship is harder to reconcile with the causal mechanism outlined in the essentialist argument. In most societies, education attainment probably does not translate into much more decision-making influence over questions of war and peace. (Except, of course, indirectly, by raising the chance that one may gain a particular position of influence, e.g., the leader of the state or a legislator in a democratic parliament. These possibilities are already covered by the measures of political gender equality.) I thus argue that to the extent H6 is supported in the tests will strengthen in particular the credibility of the constructivist argument. Seen from the perspective of the essentialist argument, H6 appears less relevant; regardless of whether H6 withstands falsification or is rejected, no clear inferences can be drawn with regard to the essentialist argument.

\section{ESTABLISHED DETERMINANTS OF INTRASTATE ARMED CONFLICT}

In his comprehensive review of the findings regarding the causes of civil war, Scott Gates concludes that "the following variables are generally agreed to be associated with a higher risk of 
civil war: (1) poverty, lack of economic opportunities, and level of economic development, (2) time since previous civil war and conflict history, (3) ethnic dominance, and (4) political instability" (Gates, 2002:9). As controls I will use several indicators for these four areas as well as a few additional variables.

To measure level of economic development, I use the natural log of GDP per capita. ${ }^{7}$ I also enter the square of the log-transformed GDP per capita measure so as to capture a curvilinear effect. Douglas Hibbs (1973) found a parabolic effect of the level of economic development so that countries near the middle of the range of this variable run the highest risk of suffering the pains of civil war, the poorest countries face a somewhat lower risk of civil war, and the richest countries are the least likely to experience this scourge. Three principal arguments have been advanced that are compatible with this pattern. The first argument explains why the relationship has the shape of an inverted "U", proposing that it is the social dislocation of modernization that intensifies class conflict and thereby raises the risk of armed conflict. As countries begin to develop economically, they enter a phase of heightened tension, but if and when they become sufficiently prosperous, the social relations tend to become more settled and class conflict to abate (Hibbs, 1973). The other two arguments explain why the richest countries are the least likely to experience the onset of internal armed conflict (or why the parabolic relationship is skewed instead of symmetrical). The one argument holds that it is the deterrent capability of richer, and therefore more powerful, states that discourages internal armed conflict (Fearon and Laitin, 2003). The other argument contends instead that it is the higher opportunity cost of giving up civilian life to become a rebel (e.g., lost income) that reduces the risk of internal armed conflict in the richer states (Collier and Hoeffler, 2001). 
The time since previous civil war is captured by a variable counting the number of years with no internal armed conflict and cubic splines that approximate the discrete time hazard rates for internal armed conflict (Beck, Katz, and Tucker, 1998). Conflict history is further taken into account using a variable that, given that an internal armed conflict is ongoing, counts the number of preceding years with uninterrupted conflict. I will also include the level of conflict lagged one year (this is further developed in the section on research design).

Ethnic dominance is a dichotomous indicator that, following Paul Collier and Anke Hoeffler (2001), is coded 1 if the largest ethnic group in a country makes up 45-80 percent of the total population. I also include a measure of ethnic heterogeneity, the so-called ethnic fractionalization index. This index measures the probability that two randomly selected persons from a given country will not belong to the same ethnic group (Mauro, 1995). The square of this index is added so as to take into account the possibility that the relationship between ethnic fractionalization and internal armed conflict may be curvilinear. ${ }^{8}$

Political instability is captured using a variable that counts the number of years since the last major change in the political institutions of the state. As a summary characteristic of the political institutions of a state, I follow common practice and use the Polity2 score which reflects the level of institutional democracy on a scale ranging from -10 (least democratic) to 10 (most democratic). Adhering to the Polity Project definition, a change in political institutions is conceived of as a three-point change in the Polity score over a period of three years or less, or the end of a transition period. ${ }^{9}$

In addition to level of economic development, conflict history, ethnic dominance and political instability, I will control for linear and curvilinear effects of institutional democracy measured as the Polity2 score and the squared Polity2 score. As robustness checks, I also add 
two dummy variables indicating regime collapse and transition, respectively, so as to capture the potentially peculiar effects of these country-years. As mentioned in the theoretical section, I will also interact the Polity2 score with one of my measures of gender equality, namely with the percentage women in parliament. Several previous works find a parabolic relationship between democracy and civil war, entailing that semi-democracies run the highest risks of being engulfed in civil war. The theoretical rationale provided for this relationship is basically that in autocracies, the willingness to rebel is likely to be high, but the opportunities to organize an opposition or rebel movement are often very limited. Whereas, in democracies the opportunity to organize is high, but the willingness to do so violently is very low; in semi-democracies both the willingness and the opportunities to rebel are believed to be quite high (Muller and Weede, 1990; Ellingsen and Gleditsch, 1997; Benson and Kugler, 1998; Ellingsen, 2000; Hegre, Ellingsen, Gates, and Gleditsch, 2001; Elbadawi and Sambanis, 2002).

I will include the natural log of the total population of a state to control for potential biases arising because of the use of thresholds in terms of the number of battle-related deaths to define minor armed conflict and war; more populous countries are more likely to cross these thresholds, especially the higher threshold of 1,000 combat deaths that define full-scale war. $^{10}$

Finally, in order to isolate the impact of the ratio of female-to-male higher education attainment, I will also include as a control a measure of the total (female plus male) education achievement in a country, namely the percentage of the population age 25 and over that has attained secondary school education. ${ }^{11}$ The independent variables are listed in Table I below. 
TABLE I IN HERE

\section{DESIGN}

I use random effects ordered logistic regression. The ordinal conflict variable ranges from peace over minor armed conflict to full-scale civil war. By way of including two dummy variables representing minor internal armed conflict in the preceding year and civil war in the preceding

year, respectively, I in effect test for the influence of the independent variables on changes in the level of conflict. By taking the lagged dependent variable into account in this way, I also control for state dependence in armed conflict. Temporal dependence in conflict years is further controlled for using a variable that, given that an internal armed conflict is ongoing, counts the number of preceding years, with uninterrupted conflict. To control for temporal dependence between peace years I add a variable counting the number of years with no internal armed conflict together with natural cubic splines that approximate the discrete time hazard rates for internal armed conflict (Beck et al., 1998).

I also lag the independent variables. ${ }^{12}$ The inclusion on the right-hand side of the equation of lagged independent variables in combination with a lagged dependent variable (in the form of the two dummies indicating lagged minor armed conflict and lagged civil war) minimizes the threat to valid inferences that causality may run from peace to gender equality. In this design any effects of $Y$ on $X$ occurring prior to $t_{-1}$ are likely to be controlled for. 
This design, which focuses changes in the level of internal armed conflict, utilizes much more information than the more traditional analysis of conflict onset. Instead of treating conflict as a dichotomous phenomenon that is either off or on, the ordered regressions take into account that there is information available on three ordered intensity levels of armed conflict. This also means that observations with ongoing conflict can be retained in the analysis (given appropriate controls for temporal dependence), instead of being discarded as is the usual practice when conflict onset is the dependent variable.

\section{RESULTS}

Table II presents the results of random effects ordered logistic regressions with the level of intrastate armed conflict as the dependent variable. Model 1 is the Complete Model with all independent variables included. Model 2 is a Trimmed Comparison Model. To arrive at Model 2, I used the same independent variables as in Model 1, except that the six measures of gender equality were left out. I then stepwise dropped non-significant variables in order of worst significance until all remaining variables were significant independently or jointly. ${ }^{13}$ The Trimmed Comparison Model then includes those variables that are significant (or jointly significant) at the 0.10 level or better. The third model in Table II is the Trimmed Gender Model, which is obtained using the same procedure but with the measures for gender equality included from the outset. 


\section{TABLE II IN HERE}

The Trimmed Gender Model will be the basis for determining whether my hypotheses are supported or rejected by the data. ${ }^{14}$ But first I will comment on the Trimmed Comparison Model so as to establish a benchmark for comparing what happens when a gender perspective is introduced. Overall, the Trimmed Comparison Model agrees with previous research. The Log of GDP per Capita at $\mathrm{t}-1$ and its squared term are significant, indicating that there is a parabolic relationship between economic development and the level of conflict within a state. This parabolic relationship is in this specification skewed so that countries with a logged GDP per capita near the 33 rd percentile of this variable (corresponding to about 1,045 dollars) run the highest risk of suffering the pains of civil war. The very poorest countries face a somewhat lower risk of civil war, whereas the richest countries are the least likely to experience civil war. All variables reflecting conflict history are statistically significant (jointly or independently, as indicated above), demonstrating that there is temporal dependence in peace as well as in intrastate armed conflict, and state dependence in the level of intrastate armed conflict. There is no significant effect of Ethnic Dominance, but Fractionalization and Fractionalization Squared are jointly significant $(\mathrm{p}=0.019)$. The measure for political instability, Years Since Regime Change $\mathrm{t}-1$ is not included in the Trimmed Comparison Model since this variable was not statistically significant. Democracy and Squared Democracy are both significant, indicating a curvilinear impact so that the level of conflict tends to be highest in semi-democracies near the middle of the democracy scale. The log of the total population is significantly associated with higher levels of conflict, whereas the log of the total education attainment is significantly associated with lower levels of conflict. To sum up, in the process of deriving the Trimmed 
Comparison Model, all variables end up being significant and having the right sign, except Ethnic Dominance and Years Since Regime Change at t-1.

Let us now turn to how the hypotheses fare in the test. The indicator of female state leadership has the wrong sign and is not significant in the Complete Model, and it fails to make it to the Trimmed Gender Model. Consequently, H1 (States with a woman leader have lower levels of internal armed conflict than states with a man as its highest leader) is rejected. As noted earlier, this variable is probably the weakest indicator of gender equality employed in this study.

$\mathrm{H} 2$ (The higher the rate of female representation in parliament, the stronger the pacifying effect of female state leadership will be) takes into account the possibility that it is support from other women in influential positions that enables women leaders to exert their distinct influence. Although it has the right sign in the complete model, the interaction term between the female state leadership indicator and the rate of female parliamentary representation is not significant, and it fails to make it to the Trimmed Gender Model. This auxiliary hypothesis is thus rejected.

There is, however, a significant pacifying effect of the rate of female representation in parliament in the Complete Gender Model as well as in the Trimmed Gender Model. H3 (The higher the rate of female representation in parliament, the lower a state's level of intrastate armed conflict will be) is thus supported. The interaction term between the rate of female representation in parliament and the critical mass indicator is far from significant, and H4 (Female representation in parliament does not affect the level of institutional armed conflict until representation exceeds one third) is rejected. H5 (The more democratic the state, the stronger the pacifying effect of female representation in parliament will be) is supported in the Complete 
Model as well as in the Trimmed Gender Model. There is, thus, both a direct effect of female parliamentary representation lowering the level of internal armed conflict (H3), as well as a likewise benign effect of the rate of female parliamentary representation in interaction with the level of institutional democracy (H5). The latter effect means that female parliamentary representation strengthens the pacifying effect of democracy, or that the level of institutional democracy reinforces the pacifying impact of female parliamentary representation, which is the same thing in statistical terms. The auxiliary essentialist argument about the importance of a minimum critical mass of female parliamentary representation $(\mathrm{H} 4)$ is, however, redundant in this context; the pacifying effect of female parliamentary representation pertains to the rate of representation in general and not specifically to rates of representation exceeding one-third. H6 (The higher the female-to-male higher education attainment ratio, the lower a state's level of intrastate armed conflict will be) is supported in the Complete Model as well as in the Trimmed Gender Model.

Taken together, the results for H3, H5 and H6 show that gender equality indeed is associated with lower levels of armed conflict within a state, as predicted. The signs of the coefficients tell us that in any given year, more equal societies are less likely to go from peace to civil war and more likely to enter peace if a civil war is ongoing, compared to less equal societies. ${ }^{15}$ That the female leadership indicator $(\mathrm{H} 1)$, and the two essentialist auxiliary hypotheses ( $\mathrm{H} 2$ and $\mathrm{H} 4)$, fared less well in the test should not in my view be seen as weakening this overall conclusion.

Figure 1 illustrates how the relationship between economic development and intrastate armed conflict differs between the Trimmed Gender Model and the Trimmed Comparison Model. 


\section{FIGURE 1 IN HERE}

In Figure 1, the y-axis represents the predicted risk that intrastate armed conflict will erupt (either minor conflict or full-scale civil war) in a country that was at peace the preceding year. Curve A illustrates the effect of the Log of GDP per Capita at $\mathrm{t}-1$ in the Trimmed Comparison Model. Curves B and C are based on the Trimmed Gender Model and illustrate the impact of two different levels of the Female-to-Male Higher Education Attainment Ratio. Curve B represents the risk at the $10^{\text {th }}$ percentile of the Female-to-Male Higher Education Attainment, and Curve C represents the risk at the $90^{\text {th }}$ percentile of this variable. The difference between the shapes of Curve A and the other two curves shows what happens to the relationship between economic development and conflict when gender equality is taken into account. The slope on the right side of the top of Curve A is much longer than the slope on the left side, indicating that the wealthiest societies face the lowest risk of armed conflict. The rounded top slightly to the left of the middle of Curve A may be interpreted as representing instability associated with modernization. Curves $\mathrm{B}$ and $\mathrm{C}$ are based on the Trimmed Gender Model, and are, in contrast, almost perfectly symmetrical so that the richest countries no longer are any less susceptible to internal armed conflict than the poorest countries. The highest predicted risk of civil war is furthermore located more to the right on the axis representing the log of GDP per capita at $\mathrm{t}-1$, indicating that relatively wealthy countries are most susceptible to conflict once gender equality is controlled for. In Curve A, the highest risk of civil war is predicted for countries about as poor as, e.g., Fiji in 1973, with a GDP per capita of 1,045 dollars. In Curves B and C, the highest risk is predicted for countries about as wealthy as, e.g., Nicaragua in 1988, with a GDP per capita of 2,623 
dollars. Taken together, these changes show that the pacifying effect of wealth is dramatically weakened when gender equality is taken into account. In particular, the relative peacefulness of the richest countries compared to the poorest countries is eradicated. The rounded top that may be interpreted as the destabilizing effect of modernization is still evident when controlling for gender equality, and a country must now achieve a much higher level of wealth until further economic progress brings stability instead of increased risk of conflict. The difference between Curves B and C illustrates the impact of the ratio of female-to-male higher education attainment.

In my dataset as well as in some previous studies (see, e.g., Kenworthy and Malami, 1999) there is a significant positive association between the level of economic development and gender equality. This implies that gender equality in relation to the statistical association between economic development and domestic peace may be an intervening variable. The result that the pacifying impact of national wealth is weakened in the Trimmed Gender Model is in line with this interpretation. Thus, whereas it seems that the destabilizing influence of modernization is relatively independent of the role of gender equality, the arguments about the deterrent effect of rich and powerful states and the opportunity costs for taking up arms in affluent societies are undermined by the introduction of measures of gender equality. It appears that national wealth exerts its pacifying influence through higher levels of gender equality rather than through deterrence or opportunity costs. In this light, the arguments about deterrence and opportunity costs seem redundant.

In the Trimmed Comparison Model there was a significant direct effect of the level of institutional democracy in the shape of a slightly skewed inverted "U", so that the level of conflict tends to be highest in semi-democracies near the middle of the democracy scale and lowest in full democracies. All three curves in Figure 2 are based on the Trimmed Gender Model 
and together illustrate how the rate of female parliamentary representation interacts with the level of institutional democracy so as to reduce the risk of conflict onset. Again, the y-axis represents the predicted risk that either of the two levels of intrastate armed conflict will erupt in a country that was at peace. Curve D shows the predicted risk of conflict onset at the $10^{\text {th }}$ percentile of the variable, reflecting the rate of female parliamentary representation. Curves $\mathrm{E}$ and $\mathrm{F}$ illustrate the risks at the $50^{\text {th }}$ and the $90^{\text {th }}$ percentiles, respectively. For any given level of democracy, the difference between the risks indicated by the three curves represents the impact of political gender equality, and this impact increases with higher levels of democracy. In the least democratic societies, the effect of political gender equality is even reversed, i.e., states with higher rates of female parliamentary representation appear to be slightly more at risk of experiencing intrastate armed conflict. The countries that at the same time have high levels of female parliamentary representation and low levels of democracy are predominantly one-party socialist states. Perhaps these regimes are especially susceptible to intrastate armed conflict or prone to appoint female parliamentarians for ideological reasons even if gender relations in reality remain very unequal.

The interaction effect illustrated in Figure 2 can also be interpreted in terms of the impact of institutional democracy. Only in Curve F, i.e., the case with the highest rate of female parliamentary representation, are the most democratic societies any less susceptible to intrastate armed conflict than the least democratic societies. Looking at Curve D, we find that full democracies with parliaments completely dominated by men are clearly more prone to intrastate armed conflict than total dictatorships. In other words, in the absence of political gender equality, institutional democracy has no pacifying impact with regard to the level of intrastate armed 
conflict. The remaining controls generally behave as expected and have almost the same impact in the Trimmed Gender Model as in the Trimmed Comparison Model.

\section{FIGURE 2 IN HERE}

Figures 1 and 2 illustrate the consequences of integrating a gender perspective for two causes of civil peace that are central in previous research: level of economical development and democracy. The figures also showed that the impact of gender equality on the risk of intrastate armed conflict is substantial. Table III further demonstrates the substantive importance of gender equality relative to the other determinants of intrastate conflict. The first four rows of Table III report the difference between the predicted risk of conflict onset when a variable is at its $10^{\text {th }}$ percentile and when it is at its $90^{\text {th }}$ percentile. The fifth row shows the predicted risks when both the two significant measures of gender equality are at their $10^{\text {th }}$ percentile and when both are at their $90^{\text {th }}$ percentile. The last three rows report predicted risks for three variables with curvilinear relationships to intrastate armed conflict: economic development, ethnic fractionalization and democracy. For these three variables the reported difference in risk pertains to the $10^{\text {th }}$ percentile and the point of maximum risk (which corresponds to a level lower than the $90^{\text {th }}$ percentile for all three variables).

\section{TABLE III IN HERE}

In Table III, the ratio of female-to-male higher education attainment has the second strongest impact (3.38\%), surpassed only by the log of the total population (5.04\%). The third largest 
effect is that of total education attainment (3.34\%), followed by the rate of female parliamentary representation (3.03\%). As Figure 2 showed, the effect of female parliamentary representation is even stronger in interaction with higher levels of democracy. Clearly, in terms of substantial importance, the two gender equality measures are in league with the other determinants of the level of intrastate armed conflict. What is more, it is natural to consider the joint effect of the ratio of female-to-male higher education attainment and female parliamentary representation since these two measures may be viewed as different aspects of gender equality in a broader sense. The level of conflict in any given year is heavily influenced by the level of conflict the preceding year, but among the remaining determinants of intrastate armed conflict, gender equality then emerges as the strongest (6.87\%).

\section{SUMMARY AND CONCLUSIONS}

In this study I have shown that gender equality, measured as the percentage women in parliament and the ratio of female-to-male higher education attainment, is associated with lower levels of armed conflict within a country. These results agree nicely with Caprioli's finding that gender equality, measured as fertility rate and percent women in the labor force, is associated with lower risks of intrastate conflict onset. I also found a statistically significant pacifying effect of the percentage women in parliament in interaction with the level of institutional democracy. The indicator for female state leadership is, however, not statistically significant. 
I find no support for the notion that it is support from below from other women in influential positions that enable women leaders to make a distinct feminine imprint on policy. Similarly, the argument that the rate of female representation must reach a minimum critical mass (equal to about one-third) before it has any noticeable effect is contradicted by the results. The pacifying effect of female parliamentary representation pertains to the rate of representation in general, and not specifically to levels of representation exceeding one-third. The critical mass argument thus seems redundant. On another note it is sometimes speculated that systems biased toward masculine values tend to promote women with such values, and that female representation thus may be inconsequential unless this underlying masculine dominance is broken (see, e.g., Sykes, 1993). Since female parliamentary representation is associated with lower levels of intrastate armed conflict, also this argument appears superfluous in the context dealt with here.

The relationship between level of economic development and intrastate armed conflict changes when the gender aspect is taken into account. When no measures of gender equality were included in the analysis, a skewed parabolic relationship between level of economic development and intrastate conflict was statistically significant. Its shape was such that countries roughly at the 33 rd percentile of the logged GDP per capita variable faced the gravest dangers of intrastate armed conflict, the richest countries being the least likely to experience higher levels of intrastate armed conflict, whereas the risk that the very poorest countries will experience higher levels of intrastate armed conflict is in between the risks facing the somewhat less poor states and the economically more developed states. This skewed parabolic shape can be interpreted as reflecting simultaneously the conflict generating effects of modernization, and the pacifying effects of having a wealthy state. 
But this relationship changes when the gender aspect is taken into account so that the richest countries no longer are any less likely to experience higher levels of intrastate armed conflict than the poorest countries. There is still an effect in the shape of an inverted "U" that reasonably can be interpreted as reflecting the pains of modernization, but the pacifying effects of having a very wealthy state are no longer evident. This leads me to question the credibility of two major arguments that have been advanced as explanations for why the richest countries supposedly are the least troubled by intrastate armed conflict, namely that the richer states are so powerful that they deter potential rebels and that the high opportunity costs of becoming a rebel in an affluent society discourage rebellion. It appears instead that the pacifying influence of economic development operates through a positive effect on gender equality, and that the arguments about deterrence and opportunity costs are superfluous at best.

Although I find that gender equality is associated with lower levels of intrastate armed conflict, my results are more ambiguous when it comes to determining how the causal mechanism connecting gender equality and peace operates. To further specify and disentangle the relationship between gender equality and peace is in the light of the findings presented in this study an important area for future research.

Achieving equality between men and women would mean rectifying a grave social injustice and would directly improve the lives of most women and girls. Also, many men would arguably benefit in various ways from being liberated from the demands imposed by a rigid gender hierarchy. What is more, this study, together with Caprioli's (Forthcoming) recent article, shows that gender equality may bring important indirect benefits as well by way of reducing the risk of armed conflict ripping societies apart from within. 


\section{APPENDIX: ROBUSTNESS CHECKS ${ }^{16}$}

As a first robustness check, I test what happens to the impact of female state leadership if two dummy variables, one indicating dynastic women leaders and the other non-dynastic women leaders, are added to the Trimmed Gender Model. ${ }^{17}$ Neither type of women leader is, however, significantly associated with the level of intrastate armed conflict.

As a second robustness check, I add two dummy variables, representing regime collapse and regime transition, respectively, as coded in Polity2. This controls for any peculiar effects that may have been hidden by the way Poility2 was adapted to time-series analyses. Neither collapse nor transition is significant.

Third, I check whether the pacifying effects of gender equality could reflect overall equality in society sooner than just gender equality. Corresponding measures that together would capture general equality in this sense, e.g., minority state leadership and minority representation in parliament, are not available for longer time series and broad cross-sections of states. I instead use two reasonable proxies that are available for relatively long periods of time and a large number of states, namely the Political Discrimination Index from the Minorities at Risk project, and the Civil Liberties Index compiled by Freedom House. The Political Discrimination Index measures the extent to which politically active ethnic groups face discrimination in terms of representation in political office and political participation. This measure is available for the years 1980-2000, but only for countries in which the Minorities at Risk project has coded the presence of at least one politically active ethnic group (Minorities at 
Risk, 2003). The Civil Liberties Index reflects the degree to which states uphold the following civil liberties: freedom of expression, assembly, association, education, and religion; an established and generally equitable system of rule of law; free economic activity; and equality of opportunity. This yearly index covers all states since 1972 (Freedom House, 2004). When added one at a time to the Trimmer Gender Model, neither the Political Discrimination Index nor the Civil Liberties Index is significant. ${ }^{18}$

Most studies on the causes of internal armed conflict and civil war have relied on a dichotomous indicator of internal armed conflict and used conflict onset as the dependent variable. As a last robustness check, I repeat my tests using this more traditional design. In these tests the dependent variable is thus a dichotomous indicator of the onset of intrastate armed conflict in the form of either minor armed conflict or full-scale civil war. When spells of ongoing conflict last more than one year, I drop all but the first year. A lot of information about the variation in intrastate conflict is discarded in these tests, but the ratio of female-to-male higher education attainment remains strongly and statistically significantly associated with lower levels of intrastate armed conflict. 


\section{BIBLIOGRAPHY}

Barro, Robert J. and Jong-Wha Lee. 2001. Barro-Lee Education Data.

$<\underline{\text { http://paradocs.pols.columbia.edu:8080/datavine/MainFrameSet.jsp }>2004,18}$

December.

Beck, Nathaniel, J. Nathaniel Katz, and Richard Tucker (1998) Taking Time Seriously: TimeSeries-Cross-Section Analysis With a Binary Dependent Variable. American Journal of

Political Science 42:1260-1288.

Benson, Michelle and Jacek Kugler (1998) Power Parity, Democracy, and the Severity of Internal Violence. Journal of Conflict Resolution 42:196-209.

Caprioli, Mary (2000) Gendered Conflict. Journal of Peace Research 37:51-68.

Caprioli, Mary (2003) Gender Equality and State Aggression: The Impact of Domestic Gender Equality on State First Use of Force. International Interactions 29:195-214. 
Caprioli, Mary (2004) Feminist IR Theory and Quantitative Methodology: A Critical Analysis. International Studies Review 6:253-269.

Caprioli, Mary (Forthcoming) Primed for Violence: The Role of Gender Equality in Predicting Internal Conflict. International Studies Quarterly.

Caprioli, Mary and Mark A. Boyer (2001) Gender, Violence, and International Crisis. Journal of Conflict Resolution 45:503-518.

Collier, Paul and Anke Hoeffler. 2001. Greed and Grievance in Civil War. $<\underline{\text { http://www.worldbank.org/research/conflict/papers/greedandgrievance.htm }>2001,}$ November 30 .

de Boer, Connie (1985) The Polls: The European Peace Movement and Deployment of Nuclear Missiles. Public Opinion Quarterly 49:119-32.

Elbadawi, Ibrahim and Nicholas Sambanis (2002) How Much War Will We See? Estimating the Prevalence of Civil War in 161 Countries, 1960-1999. Journal of Conflict Resolution 46:307-334. 
Ellingsen, Tanja (2000) Colorful Community or Ethnic Witches' Brew? Multiethnicity and Domestic Conflict During and After the Cold War. Journal of Conflict Resolution $44: 228-249$.

Ellingsen, Tanja and Nils Petter Gleditsch (1997) "Democracy and Armed Conflict in the Third World." In Causes of Conflict in Third World Countries, edited by Ketil Volden and Dan Smith, pp. 69-81. Oslo: International Peace Research Institute, Oslo.

Fearon, James D. (2003) Ethnic and Cultural Diversity by Country. Journal of Economic Growth 8:195-122.

Fearon, James D. and David D. Laitin (2003) Ethnicity, Insurgency, and Civil War. American Political Science Review 97:75-90.

Fish, Steven (2002) Islam and Authoritarianism. World Politics 55:4-37.

Fite, David, Marc Genest, and Clyde Wilcox (1990) Gender Differences in Foreign Policy Attitudes. American Political Quarterly 18:492-513.

Fleschenberg, Andrea (2003) Revisiting the Glass Ceiling in Asia: Comments on Feminist Leadership Models, Duisburg-Essen and Erlangen-Nürnberg: University of DuisburgEssen and University of Erlangen-Nürnberg. 
Frankovic, Kathy (1982) Sex and Politics - New Alignments, Old Issues. Political Science and Politics 15:439-448.

Freedom House. 2004. Freedom House. <www.freedomhouse.org > 2004, September 10.

Gates, Scott (2002) Empirically Assessing the Causes of Civil War. Paper presented at annual meeting of the International Studies Association, New Orleans, March 24-27.

Gleditsch, Kristian S. (2002) Expanded Trade and GDP Data. Journal of Conflict Resolution 46:712-724.

Gleditsch, Kristian S. 2003. Modified Polity P4 and P4D Data, Version 1.0. $<\underline{\text { http://weber.ucsd.edu/ kgledits/Polity.html }>2004, ~} 26$ March.

Gleditsch, Kristian S. 2004. Expanded Trade and GDP Data. (4.1) $<\underline{\text { http:}: / / w e b e r . u c s d . e d u / ~ k g l e d i t s / e x p t r a d e g d p . h t m l ~}>2004,18$ December.

Gleditsch, Kristian S. and Michael D. Ward (1999) Interstate System Membership: A Revised List of the Independent States since 1816. International Interactions 25:393-413.

Gleditsch, Nils Petter, Peter Wallensteen, Mikael Eriksson, Margareta Sollenberg, and Håvard Strand (2002) Armed Conflict 1946-2001: A New Dataset. Journal of Peace Research 39:615-637. 
Goldstein, Joshua S. (2001) War and Gender: How Gender Shapes the War System and Vice Versa, Cambridge: Cambridge University Press.

Hegre, Håvard, Tanja Ellingsen, Scott Gates, and Nils Petter Gleditsch (2001) Toward a Democratic Civil Peace? Democracy, Political Change, and Civil War, 1816-1992. American Political Science Review 95:33-48.

Hermann, Margaret G. (1998) One Field, Many Perspectives: Building the Foundations for Dialogue: 1998 ISA Presidential Address. International Studies Quarterly 42:605-624.

Hibbs, Douglas A. (1973) Mass Political Violence, New York: Wiley.

Inter-Parliamentary Union (1995) Women in Parliaments 1945-1995: A World Statistical Survey, Geneva: Inter-Parliamentary Union.

Inter-Parliamentary Union. 2005. Women in National Parliaments. $<$ http://www.ipu.org/wmne/classif.htm $>2004,20$ December.

Kenworthy, Lane and Melissa Malami (1999) Gender Inequality in Political Representation: A Worldwide Comparative Analysis. Social Forces 78:235-269.

Keohane, Robert O. (1998) Beyond Dichotomy: Conversations Between International Relations and Feminist Theory. International Studies Quarterly 42:193-197. 
Marchand, Marianne H. (1998) Different Communities/Different Realities/Different Encounters:

A Reply to J. Ann Tickner. International Studies Quarterly 42:199-204.

Marshall, Monty G., Ted R Gurr, Christian Davenport, and Keith Jaggers (2002) Polity IV, 1800-1999. Comparative Political Studies 35:40-45.

Mauro, Paolo (1995) Corruption and Growth. Quarterly Journal of Economics 110:681-712.

McGlen, Nancy and Meredith Reid Sarkees (1993) Women in Foreign Policy: The Insiders, New York: Routledge.

Melander, Erik (2005) Political Gender Equality and State Human Rights Abuse. Journal of Peace Research 42:149-166.

Minorities at Risk (2003) Minorities at Risk: Dataset Users Manual 040903, College Park: Center for International Development and Conflict Management (CIDCM), University of Maryland.

Muller, Edward N. and Erich Weede (1990) Cross-National Variations in Political Violence: A Rational Action Approach. Journal of Conflict Resolution 34:624-651.

Regan, Patrick M. and Aida Paskeviciute (2003) Women's Access to Politics and Peaceful States. Journal of Peace Research 40:287-302. 
Sambanis, Nicholas (2000) Partition as a Solution to Ethnic War - An Empirical Critique of the Theoretical Literature. World Politics 52:437-483.

Schemmel, B. 2004. Rulers. $<$ http://www.rulers.org $>2004,18$ December.

Shapiro, Robert and Harpreet Mahajan (1986) Gender Differences in Policy Preferences: A Summary of Trends from the 1960s to the 1980s. Public Opinion Quarterly 50:42-61.

Smith, Tom W. (1984) The Polls: Gender and Attitudes Towards Violence. Public Opinion Quarterly 48:384-396.

Sykes, Patricia Lee (1993) "Women as National Leaders: Patterns and Prospects." In Women as National Leaders, edited by Michael A. Genovese, pp. 219-229. Newbury Park, CA: Sage.

Tessler, Mark and Ina Warriner (1997) Gender, Feminism, and Attitudes Toward International Conflict. World Politics 49:250-281.

Tickner, J. Ann (1992) Gender in International Relations, New York: Colombia University Press.

Tickner, J. Ann (1997) You Just Don't Understand: Troubled Engagements Between Feminists and IR Theorists. International Studies Quarterly 41:611-632. 
Tickner, J. Ann (1998) Continuing the Conversation. International Studies Quarterly 42:205210.

Tickner, J. Ann (2001) Gendering World Politics, New York: Colombia University Press.

Togeby, Lise (1994) The Gender Gap in Foreign Policy Attitudes. Journal of Peace Research 31:375-392. 
Table I. Independent Variables Grouped by Theme

\begin{tabular}{|c|c|}
\hline Theme & Variables \\
\hline Gender Equality & $\begin{array}{l}\text { Female State Leadership }(\mathrm{H} 1) \\
\text { Female Leader *\% Women in Parliament }(\mathrm{H} 2) \\
\% \text { Women in Parliament }(\mathrm{H} 3) \\
\% \text { Women in Parliament } * \text { Critical Mass }(\mathrm{H} 4) \\
\% \text { Women in Parliament } * \text { Democracy }(\mathrm{H} 5) \\
\text { Female/Male Higher Education Attainment (H6) }\end{array}$ \\
\hline Economic Development & $\begin{array}{l}\text { Log of GDP per Capita } \\
\text { Squared Log of GDP per Capita }\end{array}$ \\
\hline Conflict History & $\begin{array}{l}\text { Number of years since last internal armed conflict (Peace } \\
\text { Years) plus cubic Splines } \\
\text { Duration of Ongoing Conflict } \\
\text { Minor Internal Armed Conflict } \\
\text { Civil War }\end{array}$ \\
\hline Ethnic Composition & $\begin{array}{l}\text { Ethnic Dominance } \\
\text { Fractionalization } \\
\text { Fractionalization Squared }\end{array}$ \\
\hline Political Stability & Years Since Regime Change \\
\hline Institutional Democracy & $\begin{array}{l}\text { Polity2 } \\
\text { Polity } 2 \text { Squared }\end{array}$ \\
\hline Total population & Log of the Total Population \\
\hline Total Education & Log of Percent Secondary School Attained \\
\hline Robustness Checks & $\begin{array}{l}\text { Dynastic Female Leader } \\
\text { Non-Dynastic Female Leader } \\
\text { Regime Collapse } \\
\text { Regime Transition } \\
\text { Minorities at Risk Political Discrimination Index } \\
\text { Freedom House Civil Liberties Index }\end{array}$ \\
\hline
\end{tabular}

Note: most independent variables are lagged one year. 
Table II. Explaining the Level of Intrastate Armed Conflict

\begin{tabular}{|c|c|c|c|}
\hline & $\begin{array}{l}\text { Complete } \\
\text { Model }\end{array}$ & $\begin{array}{l}\text { Trimmed } \\
\text { Comparison } \\
\text { Model }\end{array}$ & $\begin{array}{l}\text { Trimmed } \\
\text { Gender } \\
\text { Model }\end{array}$ \\
\hline Female State Leader (H1) & $\begin{array}{l}0.56 \\
(0.79)\end{array}$ & - & [dropped] \\
\hline Female Leader $\mathrm{t}-1 *$ Percent Women in P. t-1 (H2) & $\begin{array}{l}-0.090 \\
(0.099)\end{array}$ & - & [dropped] \\
\hline Percent Women in Parliament t-1 (H3) & $\begin{array}{l}-0.052^{* * * *} \\
(0.019)\end{array}$ & - & $\begin{array}{l}-0.041^{* *} \\
(0.017)\end{array}$ \\
\hline Percent Women in P. t-1 * Critical Mass (H4) & $\begin{array}{l}0.027 \\
(0.029)\end{array}$ & - & [dropped] \\
\hline Percent Women in P. t-1 * Democracy t-1 (H5) & $\begin{array}{l}-0.0063^{* *} \\
(0.0025)\end{array}$ & - & $\begin{array}{l}-0.0065 * * * \\
(0.0024)\end{array}$ \\
\hline Log of Female/Male Higher Education t-1 (H6) & $\begin{array}{l}-1.39 * * \\
(0.64)\end{array}$ & - & $\begin{array}{l}-1.23 * * \\
(0.59)\end{array}$ \\
\hline Log of GDP per Capita t-1 & $\begin{array}{l}3.42 * * * \\
(1.17)\end{array}$ & $\begin{array}{l}2.07 * * \\
(0.81)\end{array}$ & $\begin{array}{l}3.19 * * * \\
(1.11)\end{array}$ \\
\hline Squared log of GDP per Capita t-1 & $\begin{array}{l}-0.22 * * * \\
(0.077)\end{array}$ & $\begin{array}{l}-0.15^{* * *} \\
(0.054)\end{array}$ & $\begin{array}{l}-0.20 * * * \\
(0.073)\end{array}$ \\
\hline Peace Years & -0.25 & -0.21 & -0.19 \\
\hline Spline1 & $\begin{array}{l}(0.21) \\
-0.0046\end{array}$ & $\begin{array}{l}(0.18) \\
-0.0011\end{array}$ & $\begin{array}{l}(0.21) \\
-.00076\end{array}$ \\
\hline Spline2 & $\begin{array}{l}(0.010) \\
0.00080\end{array}$ & $\begin{array}{c}(0.0086) \\
-0.00088\end{array}$ & $\begin{array}{l}(0.0096) \\
-0.00069\end{array}$ \\
\hline Spline3 & $\begin{array}{l}(0.0035) \\
0.000075\end{array}$ & $\begin{array}{l}(0.0030) \\
0.00063\end{array}$ & $\begin{array}{l}(0.0033) \\
0.00040\end{array}$ \\
\hline Minor Conflict t-1 & $\begin{array}{l}(0.00067) \\
2.55^{* * *} \\
(0.42)\end{array}$ & $\begin{array}{l}(0.00057) \\
2.85 * * * \\
(0.36)\end{array}$ & $\begin{array}{l}(0.00064) \\
2.69 * * * \\
(0.41)\end{array}$ \\
\hline Civil War t-1 & $\begin{array}{l}5.43 * * * \\
(0.49)\end{array}$ & $\begin{array}{l}5.87 * * * \\
(0.42)\end{array}$ & $\begin{array}{l}5.64 * * * \\
(0.47)\end{array}$ \\
\hline Duration of Ongoing Conflict & $\begin{array}{l}0.087 * * * \\
(0.012)\end{array}$ & $\begin{array}{l}0.066^{* * *} \\
(0.010)\end{array}$ & $\begin{array}{l}0.084 * * * \\
(0.013)\end{array}$ \\
\hline Ethnic Dominance & $\begin{array}{l}-0.17 \\
(0.29)\end{array}$ & [dropped] & [dropped] \\
\hline Fractionalization & $\begin{array}{l}5.32 * \\
(3.09)\end{array}$ & $\begin{array}{l}2.78 \\
(1.86)\end{array}$ & $\begin{array}{l}3.15 \\
(1.97)\end{array}$ \\
\hline Squared Fractionalization & $\begin{array}{l}-4.20 \\
(2.92)\end{array}$ & $\begin{array}{l}-1.49 \\
(1.73)\end{array}$ & $\begin{array}{l}-2.14 \\
(1.89)\end{array}$ \\
\hline Years Since Regime Change t-1 & $\begin{array}{l}-0.0086^{*} \\
(0.0050)\end{array}$ & [dropped] & [dropped] \\
\hline Democracy t-1 & $\begin{array}{l}0.061^{* *} \\
(0.024)\end{array}$ & $\begin{array}{l}0.023 * \\
(0.014)\end{array}$ & $\begin{array}{l}0.070 * * * \\
(0.023)\end{array}$ \\
\hline Squared Democracy t-1 & $\begin{array}{l}-0.0094 * * * \\
(0.0036)\end{array}$ & $\begin{array}{l}-0.011 * * * \\
(0.0028)\end{array}$ & $\begin{array}{l}-0.012 * * * \\
(0.0032)\end{array}$ \\
\hline Log of Total Population t-1 & $\begin{array}{l}0.32 * * * \\
(0.081)\end{array}$ & $\begin{array}{l}0.33 * * * \\
(0.071)\end{array}$ & $\begin{array}{l}0.30 * * * \\
(0.097)\end{array}$ \\
\hline
\end{tabular}




\begin{tabular}{l|lll}
\hline Log of Percent Secondary School Attained & $-0.26^{*}$ & $-0.22^{* *}$ & $-0.29^{* *}$ \\
Cut-point 1 & $(0.16)$ & $(0.11)$ & $(0.15)$ \\
& $17.89^{* * *}$ & $12.70^{* * *}$ & $16.36^{* * *}$ \\
Cut-point 2 & $(4.53)$ & $(3.14)$ & $(4.36)$ \\
& $21.91^{* * *}$ & $16.29 * * *$ & $20.29 * * *$ \\
Observations/Countries & $(4.55)$ & $(3.16)$ & $(4.38)$ \\
\hline
\end{tabular}

Standard errors in parentheses.

$*$ significant at $10 \%$; * significant at $5 \%$; *** significant at $1 \%$ 
Table III. Relative Impact of Independent Variables ${ }^{19}$

\begin{tabular}{l|lll}
\hline Variable(s) & $\begin{array}{l}\text { P conflict at 10th } \\
\text { percentile }\end{array}$ & $\begin{array}{l}\text { P conflict at 90th } \\
\text { percentile or max P }\end{array}$ & Difference \\
\hline Female/Male Higher Edu. & $5.93 \%$ & $2.55 \%$ & $3.38 \%$ \\
$\%$ Women in P. (direct eff.) & $5.25 \%$ & $2.23 \%$ & $3.02 \%$ \\
Log of Total Population & $1.97 \%$ & $7.01 \%$ & $-5.04 \%$ \\
Total Education & $6.01 \%$ & $2.67 \%$ & $3.34 \%$ \\
\hline Both Gender Measures & $8.41 \%$ & $1.54 \%$ & $6.87 \%$ \\
\hline Log of GDP per capita & $2.05 \%$ & $3.68 \%$ & $-1.63 \%$ \\
Fractionalization & $1.79 \%$ & $4.20 \%$ & $-2.41 \%$ \\
Democracy & $1.04 \%$ & $3.42 \%$ & $-2.38 \%$ \\
\hline
\end{tabular}


Figure 1. Predicted Risk of Armed Conflict Given Log of GDP per Capita at t-1, with and without Female to Male Higher Education Attainment Ratio at t-1

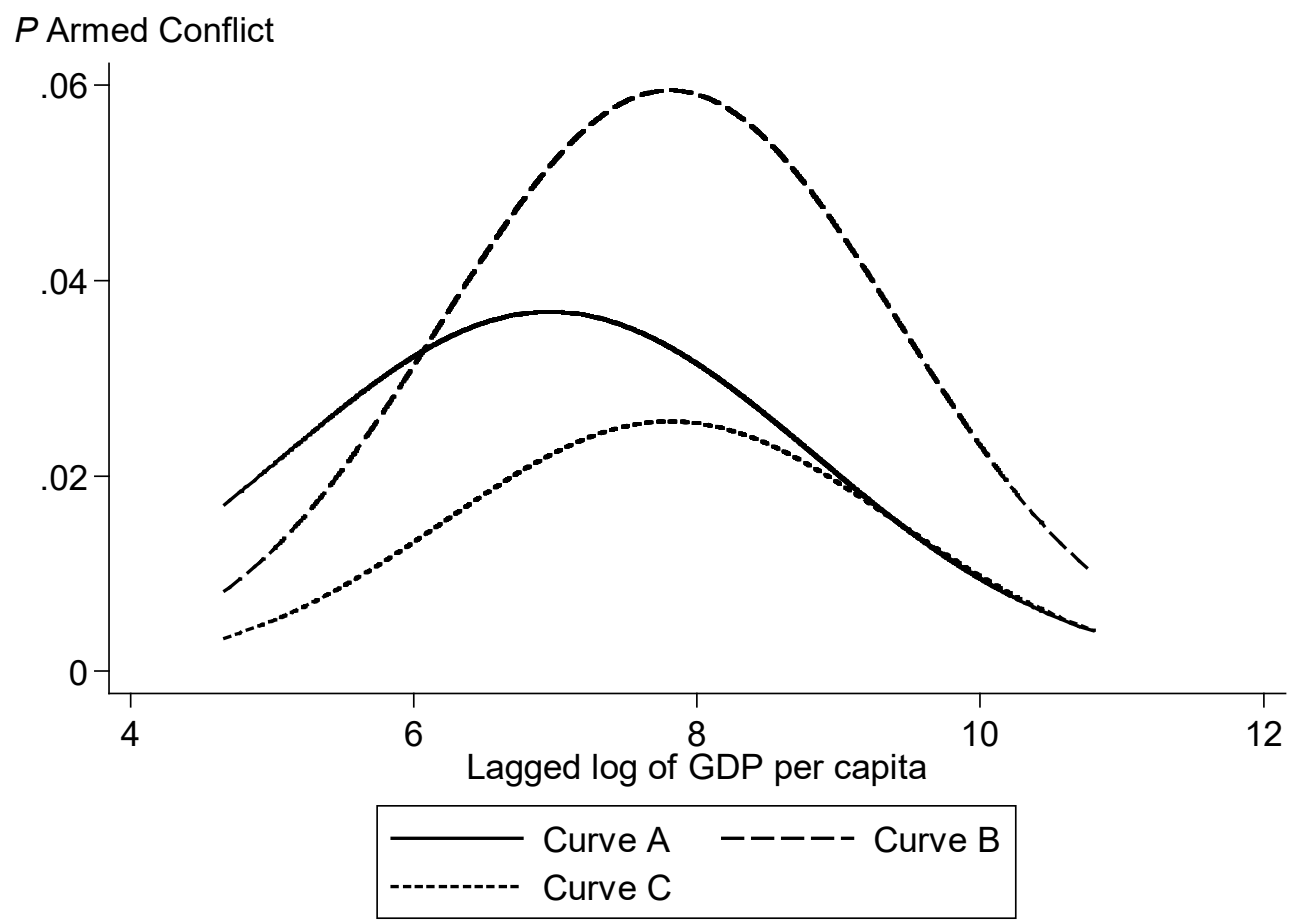

Curve A: Effect of Log of GDP per capita at $\mathrm{t}-1$ in the Trimmed Comparison Model

Curve B: Female to Male Higher Education Ratio set at $10^{\text {th }}$ percentile

(Cameroon in 1974, ratio $=0.27$ )

Curve C: Female to Male Higher Education Ratio set at $90^{\text {th }}$ percentile

(Panama in 1989, ratio $=0.99$ )

The remaining variables were set at their means with the following exceptions:

Peace Years (plus Splines): median

Minor Conflict at t-1: 0

Civil War at $\mathrm{t}-1: 0$

Duration of Conflict: 0

Log of GDP per capita at $\mathrm{t}-1$ : not altered, same as in data

Squared Log of GDP per capita at t-1: not altered, same as in data

The predicted probabilities are based on the Trimmed Comparison Model (Curve A) and the Trimmed Gender Model (Curves B and C). 


\section{Figure 2. Predicted Risk of Armed Conflict Given Female Parliamentary Representation and Democracy}

$P$ Armed Conflict

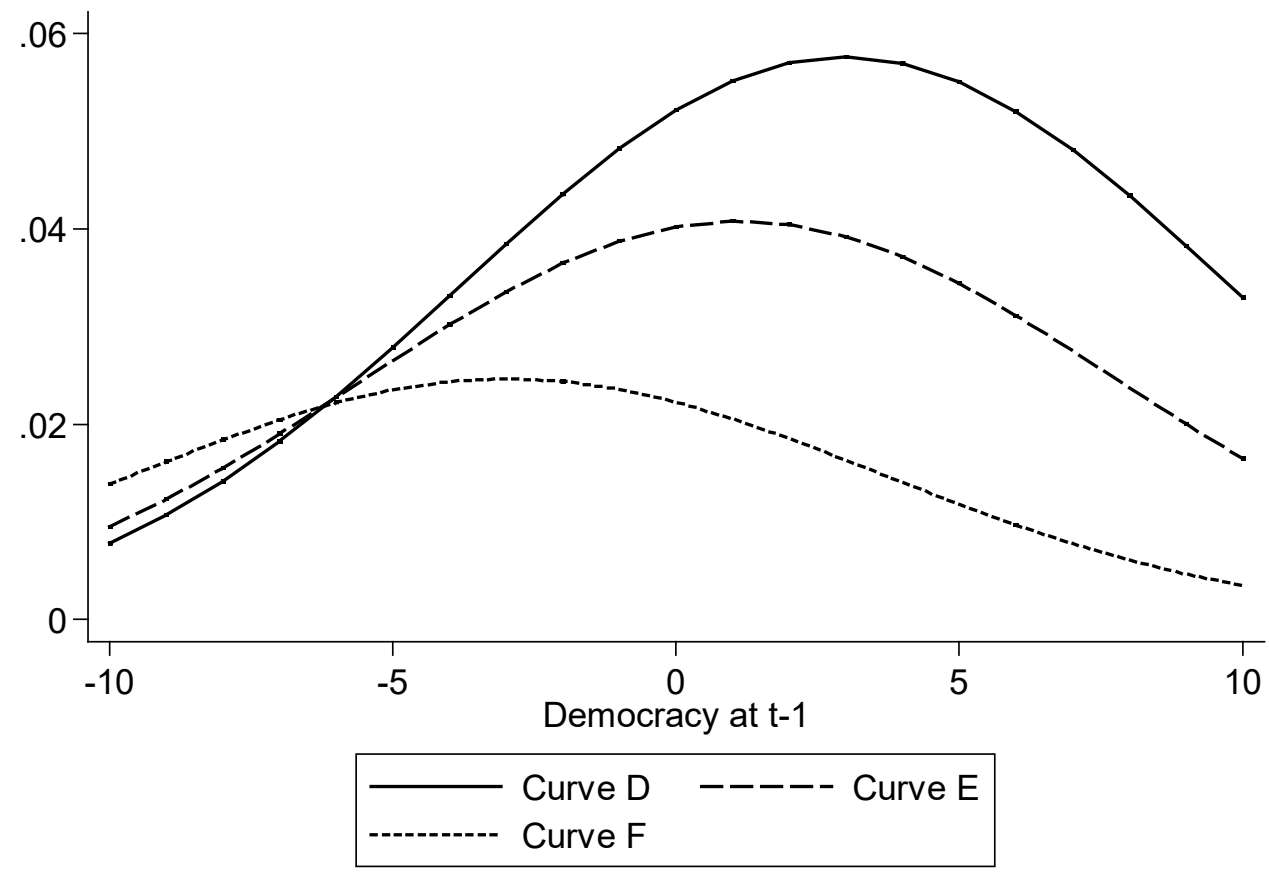

Curve D: Percent Women in Parliament set at $10^{\text {th }}$ percentile (Pakistan in 1990, 0 \% women)

Curve E: Percent Women in Parliament set at median (Israel in 1992, 6.7\% women)

Curve F: Percent Women in Parliament set at $90^{\text {th }}$ percentile (Nicaragua in 1984, 21.6\% women)

The remaining variables were set at their means with the following exceptions:

Peace Years (plus Splines): median

Minor Conflict at t-1: 0

Civil War at $\mathrm{t}-1: 0$

Duration of Conflict: 0

Democracy at $\mathrm{t}-1$ : not altered, same as in data

Democracy Squared at t-1: not altered, same as in data

The predicted probabilities are based on the Trimmed Gender Model. 
${ }^{1}$ For an overview, see Mary Caprioli (2004).

${ }^{2}$ The data comes from Robert Barro and Jong-Wha Lee (2001).

${ }^{3}$ As a robustness check, I will replicate my analysis with the dependent variable limited to intrastate armed conflict onset.

${ }^{4}$ The data on female state leadership comes from Mary Caprioli and Mark Boyer (2001) who identify female leaders during the $20^{\text {th }}$ century defined as "the president, prime minister, or any other decision maker who is essentially the "decision maker of last resort"'. (505) They also provide the following example to clarify their definition: "Thus, Edith Cresson, who was premier of France from 1991 to 1992, was not included on our list because that position is of significantly lesser importance than that of the French president." (505) I extended the data using the information available in Schemmel (2004). Female state leadership is very rare: in the period 1965-2000 does a women hold the highest leadership position in the state only in 114 country years.

${ }^{5}$ I do not separate out women leaders in states with a rate of female parliamentary representation exceeding one third, as only one such case exists in my data (Gro Harlem Brundtland, Norway, 1986-89, and 1990-96). Instead I interact the female leadership dummy with the rate of female parliamentary representation.

${ }^{6}$ The information used for coding the percentage of women holding seats in the legislature (if the parliament is not unicameral the upper house is used) was complied by the Inter-Parliamentary Union $(1995 ; 2005)$ and covers the period 1945-2004. 
${ }^{7}$ In constant U.S. dollars with the base year 1985. This data is based on the Penn World Tables 5.6, but uses additional sources and imputation techniques to reduce problems with missing values (Gleditsch, 2002; 2004).

${ }^{8}$ The data used when coding Ethnic Dominance comes from Tanja Ellingsen (2000). The ethnic fractionalization index comes from James Fearon (2003).

${ }^{9}$ The data on political institutions comes from the Polity Project, Phase IV (Marshall, Gurr, Davenport, and Jaggers, 2002), but I use a variant that has been compiled by Kristian Gleditsch (2003) so as to conform to the list of independent states by Kristian Gleditsch and Michael Ward (1999). The Polity score that I use is a variant adapted for time-series analyses called Polity2. In Polity2 years coded -88 , indicating periods of transition during which new institutions are established, are prorated across the span of the transition so as to avoid systematically losing data because of missing values. Years coded -77 , indicating complete collapse of central political authority, are for the same reason recoded to a "neutral" score of 0 . See http://www.cidcm.umd.edu/inscr/polity/index.htm.

${ }^{10}$ The source for this data is Gleditsch (2003).

${ }^{11}$ The data comes from Barro et al. (2001). The natural log is used since this measure is highly skewed.

${ }^{12}$ Except ethnic dominance and fractionalization that do not vary over time.

${ }^{13}$ I test whether the variable indicating the number of preceding years without internal armed conflict, Peace Years, is jointly significant with the natural cubic splines. I also test whether the following pairs of variables are jointly significant, since each pair together may capture a curvilinear effect: Log of GDP per capita t-1 and Squared Log of GDP per capita t-1; 
Fractionalization and Squared Fractionalization; Democracy t-1 and Squared Democracy t-1. All significance levels reported are for two-tailed tests.

${ }^{14}$ The differences between Models 1 and 3 are that all variables that were non-significant in Model 1 are left out of Model 3, and that the variable counting years since regime change loses in significance so that this variable also fails to make it to the trimmed Model 3. The stepwise elimination of non-significant variables has no important consequences for the remaining variables, i.e., all those variables that are significant from the outset in Model 1. The results of Model 3 are not affected if the measure for political stability is allowed to remain in the model.

${ }^{15}$ The direction of the effects for changes to and from the middle category, i.e., minor intrastate armed conflict in this case, are not possible to infer unambiguously from just the signs of the coefficients. Calculations not reported here confirm, however, that gender equality tends to reduce the risk of escalation from peace to minor conflict, and from minor conflict to war, and to increase the chance of de-escalation from war to minor conflict, and from minor conflict to peace.

${ }^{16}$ The regressions are available from the author on request.

${ }^{17}$ I considered dynastic factors to be decisive if the woman in question is the widow or daughter of a prime minister, president, dictator, or leader of a major political party. In the period 19642000 there are 63 country years with a dynastic female leader and 51 country years with a nondynastic female leader.

${ }^{18}$ The Civil Liberties Index is highly correlated with Polity2, the measure for institutional democracy, and I therefore drop Polity2 and its squared term for this robustness test. 
${ }^{19}$ The predicted probabilities pertain to the risk that minor intrastate armed conflict or civil war will erupt in a country that was at peace the preceding year, based on the Trimmed Gender Model. All remaining variables are set at their mean, except Duration of Ongoing Conflict, Minor Internal Armed Conflict, and Civil War that are set at zero, and Peace Years (plus Splines) that is set at the median. 